\title{
Influence of Prescribed Fire on Ecosystem Biomass, Carbon, and Nitrogen in a Pinyon Juniper Woodland
}

\author{
Benjamin M. Rau, ${ }^{1}$ Robin Tausch, ${ }^{2}$ Alicia Reiner, ${ }^{3}$ Dale W. Johnson, ${ }^{4}$ Jeanne C. Chambers, ${ }^{5}$ \\ Robert R. Blank, ${ }^{6}$ and Annmarrie Lucchesi ${ }^{7}$ \\ Authors are ${ }^{1}$ Postdoctoral Researcher, ${ }^{4}$ Professor of Soil Science, and ${ }^{7}$ Research Assistant, Department of Natural Resources and Environmental Science, \\ University of Nevada, Reno, NV 89512, USA; ${ }^{2}$ Research Range Scientist and ${ }^{5}$ Research Ecologist, US Department of Agriculture (USDA) Forest Service, \\ Rocky Mountain Research Station, Reno, NV 89512, USA; ${ }^{3}$ Fire Ecologist, USDA Forest Service, Adaptive Management Services Enterprise Team, \\ Sparks, NV 89431, USA; and ${ }^{6}$ Research Soil Scientist, USDA Agricultural Research Service, Reno, NV 89512, USA.
}

\begin{abstract}
Increases in pinyon and juniper woodland cover associated with land-use history are suggested to provide offsets for carbon emissions in arid regions. However, the largest pools of carbon in arid landscapes are typically found in soils, and aboveground biomass cannot be considered long-term storage in fire-prone ecosystems. Also, the objectives of carbon storage may conflict with management for other ecosystem services and fuels reduction. Before appropriate decisions can be made it is necessary to understand the interactions between woodland expansion, management treatments, and carbon retention. We quantified effects of prescribed fire as a fuels reduction and ecosystem maintenance treatment on fuel loads, ecosystem carbon, and nitrogen in a pinyon-juniper woodland in the central Great Basin. We found that plots containing 30\% tree cover averaged nearly $40000 \mathrm{~kg} \cdot \mathrm{ha}^{-1}$ in total aboveground biomass, $80000 \mathrm{~kg} \cdot \mathrm{ha}^{-1}$ in ecosystem carbon (C), and $5000 \mathrm{~kg} \cdot \mathrm{ha}^{-1}$ in ecosystem nitrogen (N). Only $25 \%$ of ecosystem C and $5 \%$ of ecosystem N resided in aboveground biomass pools. Prescribed burning resulted in a $65 \%$ reduction in aboveground biomass, a $68 \%$ reduction in aboveground $\mathrm{C}$, and a $78 \%$ reduction in aboveground N. No statistically significant change in soil or total ecosystem $\mathrm{C}$ or $\mathrm{N}$ occurred. Prescribed fire was effective at reducing fuels on the landscape and resulted in losses of $\mathrm{C}$ and $\mathrm{N}$ from aboveground biomass. However, the immediate and long-term effects of burning on soil and total ecosystem $\mathrm{C}$ and $\mathrm{N}$ is still unclear.
\end{abstract}

\section{Resumen}

Incrementos de los bosques de piñón y enebro relacionados con el historial del uso de la tierra se han sugerido como una forma de proveer desvíos de las emisiones de carbón en zonas áridas. Sin embargo, los más grandes reservorios de carbono en zonas áridas se encuentran originalmente en el suelo, y la biomasa aérea no puede considerarse almacenamiento a largo plazo en los ecosistemas que están propensos al fuego. También, los objetivos de almacenamiento del carbono pueden entrar en conflicto con el manejo de los servicios de los ecosistemas y la reducción de combustibles. Antes de que se tomen las decisiones adecuadas es necesario el entender las interacciones entre la expansión del bosque y los tratamientos de manejo, así como la retención de carbón. Cuantificamos los efectos de las quemas prescritas como un tratamiento en la reducción del combustible y el mantenimiento del ecosistema en cargas de combustible, carbono del ecosistema, y nitrógeno en el bosque de piñón-enebro en la gran cuenca central. Encontramos que parcelas que tenían una cubierta arbórea del $30 \%$ promediaron casi $40000 \mathrm{~kg} \mathrm{ha}^{-1}$ en total de la biomasa aérea, $80000 \mathrm{~kg}$ ha en C del ecosistema, y $5000 \mathrm{~kg}$ ha de $\mathrm{N}$ del ecosistema. Solamente el $25 \%$ del C y el $5 \%$ el N del ecosistema existe en la biomasa aérea. Las quemas prescritas reducen la biomasa aérea en un $65 \%$, así como el C aéreo en un $68 \%$, y $78 \%$ del $\mathrm{N}$ de la superficie. No se encontraron cambios estadísticamente significativos en el $\mathrm{Co} \mathrm{N}$ del suelo o del ecosistema. Las quemas prescritas fueron efectivas en la reducción del combustible en el paisaje y dieron lugar a las pérdidas de $\mathrm{C}$ y $\mathrm{N}$ de la biomasa aérea. Sin embargo, los efectos inmediatos y a largo plazo de las quemas del $\mathrm{C}$ y $\mathrm{N}$ del suelo y del total del ecosistema todavía no son muy claros.

Key Words: carbon storage, ecosystem maintenance, fuels management

\section{INTRODUCTION}

Vegetation changes associated with longer-term climate change and anthropogenic disturbance have major effects on soils,

\footnotetext{
This research was funded by the USDA Forest Service, Rocky Mountain Research Station and Joint Fire Sciences Program.

At the time of the research, Benjamin M. Rau was a postdoctoral researcher, Dept Natural Resources and Environmental Science, University of Nevada, Reno, 1000 Valley Rd, Reno, NV 89512, USA.

Correspondence: Benjamin M. Rau, Dept of Natural Resources and Environmental Science, University of Nevada, Reno, 1000 Valley Rd, Reno, NV 89512, USA. Email: brau@unr.nevada. edu
}

Manuscript received 18 June 2009; manuscript accepted 20 December 2009 vegetation, and biogeochemical cycling (Schimel et al. 1991, 1994; Hibbard et al. 2003; Bradley et al. 2006; Blank 2008; Hooker et al. 2008). Much of the Great Basin is currently dominated by sagebrush (Artemisia tridentata Nutt. subsp.) ecosystems, but at intermediate elevations with more mesic climatic regimes, sagebrush ecosystems are increasingly influenced by pinyon (Pinus monophylla Torr. \& Frém, Pinus edulis Engelm.) and juniper (Juniperus osteosperma [Torr.] Little, Juniperus occidentalis Hook.) expansion. Pinyon and juniper woodlands have expanded their pre-European settlement range in the Great Basin by more than $60 \%$ since 1860 because of climate change, fire suppression, and overgrazing by livestock (Miller and Wigand 1994; Gruell 1999; Miller and Rose 1999). 
Although pinyon-juniper woodlands have expanded and receded several times over the last $5000 \mathrm{yr}$, the current rate of expansion is unprecedented.

Some scientists hypothesize that woodland expansion could result in large increases in carbon $(\mathrm{C})$ storage within the interior west (Norris et al. 2001; Anser et al. 2003; Hibbard et al. 2003; Canadell and Raupach 2008; McKinley and Blair 2008). It is possible that increasing tree cover could temporarily increase biomass and $\mathrm{C}$ storage; however, due to the frequency of fire in Great Basin ecosystems (15-100 yr) expansion woodlands should not be considered long-term $\mathrm{C}$ storage because $\mathrm{C}$ in biomass is released to the atmosphere during fire and subsequent decomposition (Miller and Tausch 2001; Canadell and Raupach 2008; Hurteau and North 2009).

Increasing tree cover in sagebrush ecosystems can lead to a detrimental decrease in herbaceous understory biomass (Suring et al. 2005; Chambers et al. 2007). Landscapes with high tree density and compromised understory vegetation are susceptible to catastrophic wildfire and exotic grass invasions (Young and Evans 1973, Miller and Tausch 2001, Chambers 2005). Once exotic grasses such as cheatgrass (Bromus tectorum L.) establish on the landscape, a shift to annual grass dominance may result in considerably lower potential to store $\mathrm{C}$, and may create a C source by decreasing the fire-return interval (Young and Evans 1973; D'Antonio and Vitousek 1992; Bradley 2006).

Re-establishing fire as an ecosystem process through planned or unplanned fires reduces woodland cover on the landscape, maintains herbaceous species, and discourages exotic grass invasion (Miller and Tausch 2001). Carbon storage decisions must consider not only the current vegetation state, but also future states and the potential effects of climate change and exotic invasion on the fire regime associated with those states (Hurteau and North 2009). Because nitrogen (N) is often the limiting factor in semiarid systems after water, and because $\mathrm{C}$ and $\mathrm{N}$ cycling are so closely linked, it is important to understand potential changes in $\mathrm{N}$ cycling as well (Johnson and Curtis 2001).

In this study we addressed three questions: 1) How does prescribed fire affect biomass and fuel loads in Great Basin expansion woodlands? 2) How does prescribed fire influence the release of $\mathrm{C}$ and $\mathrm{N}$ from the system? 3) Which pools of $\mathrm{C}$ and $\mathrm{N}$ are most responsive to prescribed fire?

\section{METHODS}

\section{Experimental Area}

The study is located within a Joint Fire Sciences Program demonstration area in the Shoshone Mountain Range on the Humboldt-Toiyabe National Forest (Austin Ranger District) in Nye and Lander Counties, Nevada. Underdown Canyon (lat $39^{\circ} 5^{\prime} 11^{\prime \prime} \mathrm{N}$, long $\left.117^{\circ} 35^{\prime} 83^{\prime \prime} \mathrm{W}\right)$ is oriented east to west. Elevation ranges from $2072 \mathrm{~m}$ to $2346 \mathrm{~m}$. Average annual precipitation ranges from $23 \mathrm{~cm}$ at the bottom to $50 \mathrm{~cm}$ at the top of the drainage and arrives mostly as winter snow and spring rains. Average annual temperature recorded in Austin, Nevada located near the site ranges from $-7.2^{\circ} \mathrm{C}$ in January to $29.4^{\circ} \mathrm{C}$ in July. Lithology of the Shoshone range consists of welded and nonwelded silica ash flow tuff. Soils developed on alluvial fans and are classified as coarse loamy skeletal mixed frigid Typic Haploxerolls (Rau et al. 2005).
The vegetation is characterized by mountain big sagebrush (A. tridentata Nutt. subsp. vaseyana [Rydb.] Beetle), with some Wyoming sagebrush (Artemisia tridentate subsp. wyomingensis Beetle \& Young), yellow rabbitbrush (Chrysothamnus viscidiflorus Hook. [Nutt.]), single-leaf pinyon, Utah juniper, and associated herbaceous species. Bromus tectorum, an invasive annual grass, was not a large component of the study area. Vegetation occurs in patches of variable tree dominance typical of intermediate age class woodlands in the central Great Basin.

\section{Study Design and Data Collection}

The study plots were located on northeast-facing alluvial fans at elevations of $2195 \mathrm{~m}$ and $2225 \mathrm{~m}$. The plots at elevation $2195 \mathrm{~m}$ were a control, and the plots at $2225 \mathrm{~m}$ received a spring prescribed burn. Four $20 \times 50 \mathrm{~m}$ subplots were located on both the control and burn treatment. Plots were characterized by intermediate tree cover $(\approx 30 \%$ cover $)$ at both elevations and contained a mix of trees, shrubs, and interspaces. Vegetation assessments were made on all plots prior to burning in June-July 2001, and after burning in June-July 2002. US Department of Agriculture Forest Service fire personnel burned the study plots on 11-14 May 2002 (air temperature $<32^{\circ} \mathrm{C}$, relative humidity $>15 \%$, wind speed $<9 \mathrm{~m} \cdot \mathrm{s}^{-1}$, and gravimetric live fuel moisture $\approx 40 \%$ ). Fire behavior was characterized by creeping ground fire with some single and group tree torching. During the fire soil surface temperatures measured with heat-sensitive paints on metal strips reached $370^{\circ} \mathrm{C}$ under shrub canopies, $300^{\circ} \mathrm{C}$ under tree canopies, and $200^{\circ} \mathrm{C}$ at interspaces, but measurable quantities of heat were not transferred below $2 \mathrm{~cm}$ (Rau et al. 2005).

\section{Soil and Roots}

Soil pits were used to characterize the study plots. Pits were dug to a depth of $53 \mathrm{~cm}$ until large-grained alluvium $(>30 \mathrm{~cm})$ was encountered and the soil horizons were identified. Depth increments for sampling were assigned to the approximate soil $\mathrm{A}_{1}$ horizon and subsequent $15-\mathrm{cm}$ increments $(0-8,8-23,23-$ 38 , and $38-53 \mathrm{~cm})$. Bulk density samples were collected from each depth with the use of a $93-\mathrm{cm}^{3}$ soil core. To evaluate soil C and $\mathrm{N}$ soil samples were taken from three microsites (under tree, under shrub, interspace) for each depth with a 10-cm-diameter bucket auger. Sampling was conducted in November 2001 (preburn) and again in November 2002 (postburn) to determine fire effects on soil C and N. All soil was brought back to the lab, dried at $60^{\circ} \mathrm{C}$, and sieved to $2 \mathrm{~mm}$. The $<2-\mathrm{mm}$ fraction was then ground in an IKA impact head mill and analyzed for total C and $\mathrm{N}$ concentration with the use of a LECO Truspec ${ }^{\circledR} \mathrm{CN}$ analyzer. To examine site level changes in $\mathrm{C}$ and $\mathrm{N}$ content, data were transformed into $\mathrm{kg} \cdot \mathrm{ha}^{-1}$ (Rau et al. 2009a).

Root biomass was estimated for each subplot, microsite, and depth post hoc in 2005 with the use of a diamond-tipped rotary core device (Rau et al. 2009b). Coarse roots and rock were separated from soil with the use of a 2-mm sieve. Coarse roots were then separated from rock by flotation in water, dried, weighed, then ground in a UDY cyclone mill and analyzed for total C and N concentration with the use of a LECO Truspec ${ }^{\circledR}$ $\mathrm{CN}$ analyzer (Rau et al. 2009b).

For the soil profile, soil and root $\mathrm{C}$ and $\mathrm{N}\left(\mathrm{kg} \cdot \mathrm{ha}^{-1}\right)$ was summed by the four soil depths to $53 \mathrm{~cm}$. Then the total mass of soil and root $\mathrm{C}$ and $\mathrm{N}$ at each microsite was weighted by that 
microsite's cover percentage on the subplot. The sum of all three weighted microsites was the sum of soil and root $\mathrm{C}$ and $\mathrm{N}$ on each subplot.

\section{Understory Biomass and Litter}

Understory vegetation in each subplot was sampled in $501 \times$ $2 \mathrm{~m}$ microplots. Ten plots were located contiguously along five belt transects perpendicular to the long axis of the subplot. Regression was used to model biomass by species for live and dead categories of 1 -h $(<6.35 \mathrm{~mm}), 10-\mathrm{h}(6.35-25.4 \mathrm{~mm})$, 100-h (25.4-76.2 mm), and $1000-\mathrm{h}(>76.2 \mathrm{~mm})$ time-lag fuels based on field measurements of plant size, cover, and plant weight (Tausch and Tueller 1988; Reiner 2004).

Shrub litter mats were sampled under 18 yellow rabbitbrush and 36 sagebrush (a combination of mountain and Wyoming big sagebrush). A $100-\mathrm{cm}^{2}$ frame was placed approximately halfway between the stem and the outer edge of the litter mat of each shrub to collect samples representative of the entire litter mat (Brown 1982; Reiner 2004). Regression equations were developed to relate shrub litter mass to shrub cover and estimate shrub litter mass on each plot.

\section{Tree Biomass and Litter}

Tree biomass was estimated in each subplot by measuring total tree height, crown height, longest crown diameter, crown diameter perpendicular to the longest diameter, and trunk diameter just above the root crown for each individual tree rooted within the subplot. Tree biomass (1-1000-h fuels) for each plot was calculated with the use of volume vs. mass regression equations. Equations were developed with 36 trees ranging from $1 \mathrm{~m}$ to $6 \mathrm{~m}$ in height. Trees were harvested (18) before and (18) after burning, separated by time-lag fuels, dried, and weighed (Tausch 2009).

Tree litter mats were sampled under 17 pinyon pines with crown diameters ranging from $1.8 \mathrm{~m}$ to $7.0 \mathrm{~m}$. Complete crown and litter mat dimensions were collected in order to derive relationships between litter mat area and litter mat mass. One to three 33.5 -cm-diameter rings were evenly spaced on either side of the tree bole depending on its size. Litter was removed by horizon $\left(\mathrm{O}_{\mathrm{i}}, \mathrm{O}_{\mathrm{e}}\right.$, and $\left.\mathrm{O}_{\mathrm{a}}\right)$, bagged, and brought back to the lab. Litter samples were floated to remove mineral fragments, separated by fuel time-lag size, dried, and weighed. Regressions were then developed between litter biomass and tree crown area to estimate total subplot tree litter mass.

\section{Biomass Carbon and Nitrogen}

Six subsamples were randomly selected from each biomass component (grass, forb, shrub litter, live and dead shrub 11000 -h fuels, tree litter, and live and dead tree 1-1 000-h fuels) pre- and postburn for chemical analyses. Samples were ground in a Wiley ${ }^{\circledR}$ mill and analyzed for total $\mathrm{C}$ and $\mathrm{N}$ concentration with the use of a LECO Truspec ${ }^{\circledR} \mathrm{CN}$ analyzer. The percent $\mathrm{C}$ and $\mathrm{N}$ for each biomass component was multiplied by the total mass of that component in each subplot. Biomass $\mathrm{C}$ and $\mathrm{N}$ were scaled to $\mathrm{kg} \cdot \mathrm{ha}^{-1}$.

\section{Statistical Analyses}

The Kolmogorov-Smirnov test was used to test for data normality. All data were natural log transformed to meet the assumption that the data were normally distributed. Comparisons were evaluated with the use of SAS ${ }^{\circledR i}$ mixed-effects models with repeated measures and subplot as a random effect. The year by treatment interaction term was used to identify changes caused by the prescribed fire $(P<0.05)$. Means comparisons were made with Tukey's test $($ alpha $=0.05)$.

\section{RESULTS AND DISCUSSION}

\section{Biomass and Fuels}

Tree-cover values on our plots average $30 \%$ and represent total aboveground biomass approaching $40000 \mathrm{~kg} \cdot \mathrm{ha}^{-1}$. Trees represent over $80 \%$ of total biomass in these expansion woodlands (Table 1). Tree abundance relative to that of the understory can be expected to increase as the stand matures (Miller and Tausch 2001; Reiner 2004). Preburn root biomass in our plots was measured to be one-third of aboveground biomass (Table 1). This is less than some estimates of root-toshoot ratios in cold semiarid systems (Jackson et al. 1996). However, most other reports for cold deserts come from sagebrush-dominated stands that have less aboveground biomass than pinyon woodlands. It is also possible we were not able to quantify all roots because our sample depth was limited to $53 \mathrm{~cm}$.

Prescribed burning removed nearly $65 \%$ of total aboveground biomass, including $90 \%$ of herbaceous, litter, and shrub fuels (Table 1). Observations from the site show that herbaceous fuels recovered to preburn levels by summer of 2003 (Dhaemers 2006). Burning also removed 56\% of tree biomass with over $90 \%$ of foliage and 1-h fuels being removed, leaving predominantly $10-\mathrm{h}, 100-\mathrm{h}$, and $1000-\mathrm{h}$ fuels (Table 1). Aboveground biomass remaining on our plots following the fire was approximately $15000 \mathrm{~kg} \cdot \mathrm{ha}^{-1}$ (Table 1). Prescribed burning resulted in a $33 \%$ reduction in root biomass on our plots measured 3 yr following the burn (Table 1).

\section{Ecosystem Carbon}

Preburn soil pools accounted for the largest proportion of total ecosystem $\mathrm{C}$ (Table 2). The magnitude of soil $\mathrm{C}$ to a depth of $53 \mathrm{~cm}$ in our plots $\left(50000-75000 \mathrm{~kg} \cdot \mathrm{ha}^{-1}\right)$ is similar to values obtained from sagebrush plots sampled to $100 \mathrm{~cm}(62000$ $72000 \mathrm{~kg} \cdot \mathrm{ha}^{-1}$; Hooker et al. 2008). Preburn aboveground biomass on our plots accounted for just over $20 \%$ of ecosystem C (Table 2). Trees accounted for $85 \%$ of aboveground C, whereas shrubs and litter comprised about $7 \%$ each, and herbaceous biomass accounted for less than $1 \%$ of aboveground C (Table 2). Our estimates for $\mathrm{C}$ stored in aboveground biomass in transition woodlands are lower than values reported by similar studies in sagebrush $\left(3800 \mathrm{~kg} \cdot \mathrm{ha}^{-1}\right.$; Hooker et al. $2008)$ and pinyon woodlands $\left(67500 \mathrm{~kg} \cdot \mathrm{ha}^{-1}\right.$; Klopatek et al. 1991). However, additional measurements from this study show that as stands mature and crown cover increases, aboveground C increases to approximately 70000 $\mathrm{kg} \cdot \mathrm{ha}^{-1}$ in closed-canopy pinyon stands. Root $\mathrm{C}$ accounts for about $5 \%$ of total ecosystem $\mathrm{C}$ in our study, but may play a very important role in long-term $\mathrm{C}$ storage because roots exude carbohydrates and fine roots turn over very rapidly in soils, providing a substrate for microorganisms to convert to less 
Table 1. Means, standard errors (SE), statistical letter group (SLG), mass change, and percent change for individual biomass components before and after the prescribed burn on control and burn plots. Asterisks indicate a significant change $(P<0.05)$.

\begin{tabular}{|c|c|c|c|c|c|c|c|c|}
\hline & \multicolumn{2}{|c|}{ Mass $2001(\mathrm{~kg} \cdot \mathrm{ha})$} & \multicolumn{2}{|c|}{ Mass $2002(\mathrm{~kg} \cdot \mathrm{ha})$} & \multirow{2}{*}{\multicolumn{2}{|c|}{$\begin{array}{l}\text { Mass change } \\
\left(\mathrm{kg} \cdot \mathrm{ha}^{-1}\right)\end{array}$}} & \multirow{2}{*}{\multicolumn{2}{|c|}{ Mass change (\%) }} \\
\hline & Control 2001 & Burn 2001 & Control 2002 & Burn 2002 & & & & \\
\hline & Mean (SE), SLG & Mean (SE), SLG & Mean (SE), SLG & Mean (SE), SLG & Control & Burn & Control & Burn \\
\hline Roots $0-53 \mathrm{~cm}^{1}$ & 13242 (1606), A & 13242 (1606), A & $13242(1606) \mathrm{A}$ & 8808 (559), B* & 0 & -4433 & $0 \%$ & $-33 \%$ \\
\hline Herbaceous understory & 388 (37), A & 297 (24), A & 309 (44), AB & $26(8), B^{*}$ & -78 & -271 & $-20 \%$ & $-91 \%$ \\
\hline Shrub litter & 1052 (136), A & 1304 (241), A & 804 (271), AB & $130(24), B^{*}$ & -248 & -1173 & $-24 \%$ & $-90 \%$ \\
\hline Shrub foliage & 435 (64), A & 575 (104), A & $283(90), A B$ & $58(10), B^{\star}$ & -152 & -517 & $-35 \%$ & $-90 \%$ \\
\hline Shrub $1 \mathrm{~h}$ & 1020 (163), AB & 1322 (237), A & 549 (181), AB & $132(24), B^{*}$ & -471 & -1190 & $-46 \%$ & $-90 \%$ \\
\hline Shrub $10 \mathrm{~h}$ & 693 (82), A & 835 (145), A & 460 (150), A & $83(14), B^{*}$ & -234 & -751 & $-34 \%$ & $-90 \%$ \\
\hline Shrub $100 \mathrm{~h}$ & 1031 (126), A & 1151 (212), A & 651 (217), AB & $288(53), B^{*}$ & -380 & -863 & $-37 \%$ & $-75 \%$ \\
\hline Shrub $1000 \mathrm{~h}$ & $10(3), N / A$ & $0(0), N / A$ & $1(1), N / A$ & $0(0), N / A$ & -8 & 0 & $-85 \%$ & $0 \%$ \\
\hline Shrub total & 2779 (591), AB & 3490 (910), A & 1555 (648), AB & $538(100), B^{*}$ & -1224 & -2951 & $-44 \%$ & $-85 \%$ \\
\hline Tree litter & 3184 (1124), AB & 3830 (1178), A & 2819 (1018), AB & $307(61), B^{*}$ & -365 & -3523 & $-11 \%$ & $-92 \%$ \\
\hline Tree foliage & 4684 (1004), A & 5659 (914), A & 4809 (858), A & 410 (111), $B^{*}$ & 125 & -5248 & $3 \%$ & $-93 \%$ \\
\hline Tree $1 \mathrm{~h}$ & 2725 (718), A & 3807 (758), A & 2975 (656), AB & 937 (219), $B^{\star}$ & 250 & -2870 & $9 \%$ & $-75 \%$ \\
\hline Tree $10 \mathrm{~h}$ & 4566 (956), A & 4531 (875), A & 4659 (813), A & 2734 (413), A & 92 & -1797 & $2 \%$ & $-40 \%$ \\
\hline Tree $100 \mathrm{~h}$ & 5486 (1380), A & 5013 (1490), A & 5694 (1185), A & 3266 (812), A & 208 & -1748 & $4 \%$ & $-35 \%$ \\
\hline Tree $1000 \mathrm{~h}$ & 9496 (2769), A & 10985 (2 038), A & 10116 (2421), A & 4139 (1101), A & 620 & -6845 & $7 \%$ & $-62 \%$ \\
\hline Tree total & 30981 (6359), A & 30849 (5731), AB & 31701 (5 422), AB & 13542 (2 402), $B^{*}$ & 720 & -17308 & $2 \%$ & $-56 \%$ \\
\hline Aboveground total & 38029 (6 643), A & 39356 (5 907), AB & 36879 (5 938), AB & 14485 (2 350), $B^{*}$ & -1151 & -24871 & $-3 \%$ & $-63 \%$ \\
\hline
\end{tabular}

${ }^{1}$ Roots were measured post hoc in 2005.

labile forms of soil C (Table 2; Schlesinger 1977; Schimel 1995; Strand et al. 2008).

Burning released $13000 \mathrm{~kg} \cdot \mathrm{ha}^{-1} \mathrm{C}$ from aboveground biomass on our plots (Table 2). This is consistent with the only other study we could find measuring $\mathrm{C}$ loss from fire in pinyon and juniper woodlands $\left(12600 \mathrm{~kg} \cdot \mathrm{ha}^{-1}\right.$; Klopatek et al. 1991). Burning consumed $90 \%$ of herbaceous, litter, and shrub C and $90 \%$ of fine aerial fuel C (foliage and $1 \mathrm{~h}$ ), leaving predominantly $10-\mathrm{h}, 100-\mathrm{h}$, and $1000-\mathrm{h}$ woody C (Table 2 ). Over time these residues likely will fall to the ground and a large portion $(85-92 \%)$ of this remaining pool will be lost as microbial respiration, but some will be incorporated into soils (Johnson and Curtis 2001). Prescribed burning resulted in a $31 \%$ reduction in root $\mathrm{C}$ as observed $3 \mathrm{yr}$ following the burn (Table 2). In addition to tree and shrub roots decomposing after fire, it is possible that some losses in root $\mathrm{C}$ are being offset by new fine roots from perennial herbaceous vegetation re-establishing on the site (Rau et al. 2009b). Although prescribed fire had significant impacts on aboveground $\mathrm{C}$ pools and root $\mathrm{C}$, we were unable to detect a statistically significant change in soil C, although chemical analyses of soil samples show that $\mathrm{C}$ concentrations increase near the surface following fire (Rau et al. 2009a). Similarly, because soil C is such a large portion of total ecosystem $\mathrm{C}$ there was no significant change in total ecosystem $\mathrm{C}$ following the prescribed fire.

\section{Ecosystem Nitrogen}

Prior to burning total ecosystem $\mathrm{N}$ averaged greater than $5000 \mathrm{~kg} \cdot \mathrm{ha}^{-1}$. Total soil nitrogen accounted for over $90 \%$ of total $\mathrm{N}$ on the site. Roots and total aboveground biomass only accounted for $2 \%$ and $4.5 \%$ of the total $\mathrm{N}$, respectively (Table 2). Soil $\mathrm{N}$ on our plots was six times higher than values reported by Klopatek et al. (1991) for pinyon and juniper woodlands, although their study only sampled soil to $20 \mathrm{~cm}$. Soil $\mathrm{N}$ on our plots is similar to sagebrush plots sampled to $100 \mathrm{~cm}$ by Hooker et al. $\left(2008 ; 7000-8000 \mathrm{~kg} \cdot \mathrm{ha}^{-1}\right)$.

Prescribed burning removed $227 \mathrm{~kg} \cdot \mathrm{ha}^{-1}$ or roughly $80 \%$ of aboveground $\mathrm{N}$ (Table 2). Nearly $90 \%$ of herbaceous, litter, and shrub $\mathrm{N}$ was removed (Table 2). This value is similar to values reported for other pinyon and juniper woodlands $\left(167 \mathrm{~kg} \cdot \mathrm{ha}^{-1}\right.$; Klopatek et al. 1991). Although a large proportion of aboveground $\mathrm{N}$ was lost during the fire, the amount of $\mathrm{N}$ removed from aboveground biomass represents less than $5 \%$ of total ecosystem $\mathrm{N}$ (Table 2). Although prescribed burning removed $\mathrm{N}$ from aboveground pools, no significant reduction in root $\mathrm{N}$ was observed $3 \mathrm{yr}$ following the burn, and no significant change in soil $\mathrm{N}$ occurred. However, similar to $\mathrm{C}$ there were observed increases in soil $\mathrm{N}$ concentrations in near surface soils after the burn (Rau et al. 2009a).

\section{MANAGEMENT IMPLICATIONS}

Prescribed burning was effective at reducing total aboveground biomass within our central Nevada study plots. Due to the stratified sampling design and low number of replicates in our study, fire effects on soil $\mathrm{C}$ and $\mathrm{N}$ pools were highly variable, not statistically significant, and difficult to interpret. However, some increases in soil C and $\mathrm{N}$ could have occurred. Spatial heterogeneity and measurement uncertainty in soil $\mathrm{C}$ and $\mathrm{N}$ pools is a challenge when assessing whole ecosystem changes associated with vegetation change and land management because of the large proportion of these elements in soil. Researchers and managers must take care to quantify existing soil $\mathrm{C}$ and $\mathrm{N}$ pools, and changes that may occur due to treatments, adequately. Although prescribed fire caused imme- 
Table 2. Means, standard errors (SE), statistical letter group (SLG), mass change, and percent change for ecosystem component carbon and nitrogen mass before and after the prescribed fire on control and burn plots. Asterisks indicate a significant change $(P<0.05)$.

\begin{tabular}{|c|c|c|c|c|c|c|c|c|}
\hline & \multicolumn{2}{|c|}{ Carbon mass $2001(\mathrm{~kg} \cdot \mathrm{ha})$} & \multicolumn{2}{|c|}{ Carbon mass $2002(\mathrm{~kg} \cdot \mathrm{ha})$} & & & & \\
\hline & Control 2001 & Burn 2001 & Control 2002 & Burn 2002 & \multicolumn{2}{|c|}{ Mass change $\left(\mathrm{kg} \cdot \mathrm{ha}^{-1}\right)$} & \multicolumn{2}{|c|}{ Mass change $(\%)$} \\
\hline & Mean (SE), SLG & Mean (SE), SLG & Mean (SE), SLG & Mean (SE), SLG & Control & Burn & Control & Burn \\
\hline Soil & 67448 (3238), $A B$ & 48874 (2678), B & 76949 (3953), A & 70368 (9777), AB & 9501 & 21494 & $14 \%$ & $44 \%$ \\
\hline Roots $^{1}$ & 4242 (509), AB & 4288 (717), A & 4242 (509), AB & 2956 (147), B* & 0 & -1332 & $0 \%$ & $-31 \%$ \\
\hline Litter & 1475 (472), $A B$ & 2204 (318), A & 1863 (730), A & $166(20), B^{*}$ & 388 & -2038 & $26 \%$ & $-92 \%$ \\
\hline Herbaceous & $118(28), A B$ & $130(8), A$ & 90 (31), AB & $12(4), B^{*}$ & -27 & -118 & $-23 \%$ & $-91 \%$ \\
\hline Shrub & 1412 (146), AB & 1616 (154), A & 943 (85), B & $275(7), C^{\star}$ & -469 & -1341 & $-33 \%$ & $-83 \%$ \\
\hline Tree & 16744 (2563), AB & 15901 (1117), A & 13723 (3763), AB & $5889(728), B^{\star}$ & -3021 & -10012 & $-18 \%$ & $-63 \%$ \\
\hline \multicolumn{9}{|l|}{ Aboveground } \\
\hline biomass & 19748 (2051), AB & 19851 (1489), A & 16620 (4565), AB & $6342(717), B^{\star}$ & -3129 & -13509 & $-16 \%$ & $-68 \%$ \\
\hline \multirow[t]{4}{*}{ Total ecosystem } & 91438 (4 467), A & 73013 (2 008), A & 97810 (6566), A & 79666 (8 934), A & 6372 & 6653 & $7 \%$ & $9 \%$ \\
\hline & \multicolumn{2}{|c|}{ Nitrogen mass $2001\left(\mathrm{~kg} \cdot \mathrm{ha}^{-1}\right)$} & \multicolumn{2}{|c|}{ Nitrogen mass $2002\left(\mathrm{~kg} \cdot \mathrm{ha}^{-1}\right)$} & & & & \\
\hline & Control 2001 & Burn 2001 & Control 2002 & Burn 2002 & \multicolumn{2}{|c|}{ Mass change $\left(\mathrm{kg} \cdot \mathrm{ha}^{-1}\right)$} & \multicolumn{2}{|c|}{ Mass change $(\%)$} \\
\hline & Mean (SE), SLG & Mean (SE), SLG & Mean (SE), SLG & Mean (SE), SLG & Control & Burn & Control & Burn \\
\hline Soil & 5376 (247), A & 4467 (196.9), A & 5351 (226), A & 5294 (268), A & -25 & 827 & $0 \%$ & $19 \%$ \\
\hline Roots $^{1}$ & $110(14), A$ & 112 (19.3), A & $110(14), A$ & $102(3), A$ & 0 & -10 & $0 \%$ & $-9 \%$ \\
\hline Litter & 66 (18), AB & 100 (7.7), A & 61 (19), AB & $8(1), B^{*}$ & -5 & -92 & $-8 \%$ & $-92 \%$ \\
\hline Herbaceous & $3(1), A$ & $3(0.2), A$ & $3(1), A$ & $0(0), B^{*}$ & -1 & -3 & $-18 \%$ & $-87 \%$ \\
\hline Shrub & $12(1), A$ & 13 (1.8), A & $10(1), A$ & $2(0), B^{\star}$ & -2 & -11 & $-13 \%$ & $-86 \%$ \\
\hline Tree & $161(11), A$ & 175 (8.8), A & 167 (22), A & $53(1), B^{*}$ & 6 & -122 & $4 \%$ & $-70 \%$ \\
\hline \multicolumn{9}{|l|}{ Aboveground } \\
\hline biomass & 242 (14), A & 291, (16.0), A & 240 (19), A & $63(1), B^{*}$ & -1 & -227 & $-1 \%$ & $-78 \%$ \\
\hline Total ecosystem & 5728 (244), A & 4870 (218.3), A & 5701 (231), A & 5459 (268), A & -26 & 589 & $0 \%$ & $12 \%$ \\
\hline
\end{tabular}

${ }^{1}$ Roots were measured post hoc in 2005.

diate decreases in aboveground $\mathrm{C}$ content, this short-term loss must be placed into perspective with regard to the risks of wildfire and long-term processes that drive $\mathrm{C}$ and $\mathrm{N}$ accumulation and retention. Fire-induced losses of $\mathrm{C}$ and $\mathrm{N}$ from the existing condition may not constitute net loss when viewed from the perspective of a woodland developing from a treeless sagebrush stand. Ultimately the total net gain or loss of ecosystem $\mathrm{C}$ and $\mathrm{N}$ caused by woodland expansion and burning could be determined by the completeness of decomposition, and the vegetation that returns to the site following the burn (D'Antonio and Vitousek 1992; Johnson and Curtis 2001). If a healthy sagebrush or low-density woodland system returns to the site, then perhaps $\mathrm{C}$ and $\mathrm{N}$ are gained following fire, even if all standing dead biomass decomposes. If an annual grass monoculture invades the site and the fire-return interval decreases, then the ecosystem may become a C source. These data represent an initial effort to quantify the effects of prescribed burning as a fuel-reduction treatment on wholeecosystem $\mathrm{C}$ and $\mathrm{N}$ in expansion pinyon and juniper woodlands. Further work must be done to quantify the effects of burning on soils, to assess the effects of burning over a broad range of tree cover and abiotic conditions, and to determine the effects of burning over longer time periods.

\section{ACKNOWLEDGMENTS}

This paper is Contribution Number 23 of the Sagebrush Steppe Treatment Evaluation Project (SageSTEP).

\section{LITERATURE CITED}

Anser, G. P., S. A. Archer, R. F. Hughes, R. J. Ansleys, and C. A. Wessman. 2003. Net changes in regional woody vegetation cover and carbon storage in Texas drylands, 1937-1999. Global Change Biology 9:316-335.

BLANK, R. R. 2008. Biogeochemistry of plant invasion: a case study with downy brome (Bromus tectorum). Invasive Plant Science and Management 1:226-238.

Bradley, B. A., R. A. Houghton, J. F. Mustard, and S. P. Hamburg. 2006. Invasive grass reduces aboveground carbon stocks in shrublands of the western US. Global Change Biology 12:1815-1822.

Brown, J. K. 1982. Fuel and fire behavior prediction in big sagebrush. Ogden, UT, USA: USDA Forest Service, Research Paper INT-290. 48 p.

Canadell, J. G., and M. R. Raupach. 2008. Managing forests for climate change mitigation. Science 320:1456-1457.

Chambers, J. C., B. A. Roundy, R. R. Blank, S. E. Meyer, and A. Whttaker. 2007. What makes Great Basin sagebrush ecosystems invasible by Bromus tectorum? Ecological Monographs 77(1):117-145.

D’Antonio, C. M., And P. M. Vitousek. 1992. Biological invasions by exotic grasses, the grass/fire cycle, and global change. Annual Review of Ecological Systems 23:63-87.

Dhaemers, J. M. 2006. Effects of fire and rehabilitation seeding on sagebrush communities and sage grouse habitat in the pinyon-juniper zone [thesis]. Reno, NV, USA: University of Nevada, Reno. 49 p.

Gruel, G. E. 1999. Historical and modern roles of fire in pinyon-juniper. In: S. B. Monsen and R. Stevens (comps.). Proceedings: ecology and management of pinyon-juniper communities in the interior west. Proceedings RMRS-P-9. Ogden, UT, USA: US Department of Agriculture Forest Service Rocky Mountain Research Station. p. 24-28.

Hibbard, K. A., D. S. Schimel, S. Archer, D. S. OJima, and W. Parton. 2003. Grassland to woodland transitions: integrating changes in landscape structure and biogeochemistry. Ecological Applications 13:911-926. 
Hooker, T. D., J. M. Stark, U. Norton, J. A. Leffler, M. Peek, and R. Ryel. 2008. Distribution of ecosystem $\mathrm{C}$ and $\mathrm{N}$ within contrasting vegetation types in a semiarid rangeland, in the Great Basin, USA. Biogeochemistry 90:291-308.

Hurteau, M., and M. North. 2009. Fuel treatment effects on tree-based forest carbon storage and emissions under modeled wildfire scenarios. Frontiers in Ecology and the Environment 7:409-414.

Jackson, R. B., J. Candell, J. R. Eleringer, H. A. Mooney, O. E. Sala, and E. D. Schulze. 1996. A global analysis of root distributions for terrestrial biomes. Oecologia 108:398-411.

Johnson, D. W., And P. S. CuRTIS. 2001. Effects of forest management on soil $C$ and N storage: meta analysis. Forest Ecology and Management 140:227-238.

Klopatek, J. M., C. C. Klopatek, and L. F. Debano. 1991. Fire effects on nutrient pools of woodland floor materials and soils in a pinyon-juniper ecosystem. In: S. C. Nodvin and T. A. Waldrop [EDS.]. Fire and the environment. Proceedings of an International Symposium; 20-24 March 1990; Knoxville, TN, USA; Gen Tech. Rep. SE-69. Asheville, NC, USA: US Department of Agriculture Forest Service, Southeastern Forest Experiment Station. 429 p.

McKinley, D. C., AND J. M. BlaiR. 2008. Woody plant encroachment by Juniperus virginianna in a mesic native grassland promotes rapid carbon and nitrogen accrual. Ecosystems 11:454-468.

MilleR, R. F., AND J. A. Rose. 1999. Fire history and western juniper encroachment in sagebrush steppe. Journal of Range Management 52:550-559.

Miller, R. F., and R. J. Tausch. 2001. The role of fire in juniper and pinyon woodlands: a descriptive analysis. In: K. E. M. Gallet and T. P. Wilson [EDs.]. Proceedings of the invasive species workshop: the role of fire in the control and spread of invasive species. Miscellaneous Publications No. 11. Tallahassee, FL, USA: Tall Timbers Research Station. p. 15-30.

Miller, R. F., and P. E. Wigand. 1994. Holocene changes in semi arid pinyonjuniper woodlands: response to climate, fire, and human activities in the U.S. Great Basin. Bioscience 44:465-474.

Norris, M. D., J. M. BlaiR, L. C. Johnson, and R. B. McKane. 2001. Assessing changes in biomass, productivity, and $\mathrm{C}$ and $\mathrm{N}$ stores following Juniperus virginiana forest expansion into tallgrass prairie. Canadian Journal of Forest Research 31:1940-1946.

Rau, B. M., J. C. Chambers, R. R. Blank, and W. W. Miller. 2005. Hydrologic response of a central Nevada pinyon-juniper woodland to prescribed fire. Rangeland Ecology and Management 56:614-622.
Rau, B. M., D. W. Johnson, R. R. Blank, and J. C. Chambers. 2009a. Soil carbon and nitrogen in a Great Basin pinyon-juniper woodland: influence of vegetation, burning, and time. Journal of Arid Environments 73(4):472-479.

Rau, B. M., D. W. Johnson, J. C. Chambers, R. R. Blank, and A. Luccesi. $2009 \mathrm{~b}$. Estimating root biomass and distribution after fire in a Great Basin woodland using cores and pits. Western North American Naturalist 69(4):459-468.

ReIneR, A. L. 2004. Fuel load and understory community changes associated with varying elevation and pinyon-juniper dominance [thesis]. Reno, NV, USA: University of Nevada, Reno. 63 p.

Schimel, D. S. 1995. Terrestrial ecosystems and the carbon cycle. Global Change Biology 1:77-91.

Schimel, D. S., B. H. Braswell, E. A. Holland, R. McKeown, D. S. Ojima, T. H. Painter, W. J. Parton, and A. R. Townsend. 1994. Climatic, edaphic, and biotic controls over storage and turnover of carbon in soils. Global Biogeochemical Cycles 8:279-293.

Schimel, D. S., T. G. F. Kittel, and W. J. Parton. 1991. Terrestrial biogeochemical cycles: global interactions with the atmosphere and hydrology. Tellus 43AB:188-203.

SChlesinger, W. H. 1977. Carbon balance in terrestrial detritus. Annual Review of Ecology and Systematics 8:51-58.

Strand, A. E., S. G. Pritchard, M. L. McCormack, M. A. Davis, and R. Oren. 2008. Irreconcilable difference: fine-root life spans and soil carbon persistence. Science 319:456-458.

Suring, L. H., M. J. Wisdom, R. J. Tausch, R. F. Miller, M. M. Rowland, L. S. Schueck, AND C. W. MeINKE. 2005. Chapter 4: modeling threats to sagebrush and other shrubland communities. In Part II: regional assessment of habitats for species of conservation concern in the Great Basin. In: M. J. Wisdom, M. M. Rowland, and L. H. Suring [EDS.]. Habitat threats in the sagebrush ecosystem-methods of regional assessment and applications in the Great Basin. Lawrence, KS, USA: Alliance Communications Group. p. 114-149.

TAusch, R. J. 2009. A structurally based analytic model for estimation of biomass and fuel loads of woodland trees. Natural Resources Modeling 22:463-488.

Tausch, R. J., And P. T. Tueller. 1988. Comparison of regression methods for predicting single leaf pinyon phytomass. Great Basin Naturalist 48:39-45.

Young, J. A., and R. A. Evans. 1973. Downy brome-intruder in the succession of big sagebrush communities in the Great Basin. Journal of Range Management 26:410-415. 